\title{
Teaching Science Using Dye-sensitized Solar Cells Kit
}

\section{Mr. Thomas Neil Dempsey, Forestville Central School}

High School Math and Engineering Teacher for 26 years

\section{Mr. M. Raymond Ng, Cathedral Preparatory School}

Mr. M. Raymond Ng graduated with a Master of Arts from Sam Houston State University, Huntsville, Texas and a Bachelor of Science from Edinboro University of Pennsylvania. He has been on the faculty of Cathedral Preparatory School since 2009. Mr. Ng's teaching assignments include Introduction to Computer Programming, Introduction to Robotics, Exploratory Engineering, 3D Printing and Modeling, Computer-Aided Design/Drafting, and various mathematics classes. He has participated in the NSF's Research Experiences for Teachers (RET) in Manufacturing Simulation and Automation in PSU Behrend. He researches topics including 3D Printing in 2018 and in the Dye-Sensitized Solar Cells Experiment in 2019. Since 2016, he, also, has assisted the Cathedral Preparatory School technology department's "Shark Tank" competitions. Also, he has advised Cathedral Preparatory School students for The Institute of Industrial and Systems Engineering high school poster competition in 2020. In addition, he has coached Erie Preparatory School teams (Cathedral Preparatory School and Villa Maria Academy) for the United States Academic Decathlon and Academic Sports League competitions from 2010 to 2016.

\section{Mr. Zachary Rhodes}

Dr. Jiawei Gong, The Pennsylvania state university, The Behrend College

Dr. Jiawei Gong is an assistant professor or Mechanical Engineering at The Pennsylvania state university, The Behrend College.

\section{Dr. Faisal Aqlan, The Pennsylvania State University, The Behrend College}

Dr. Faisal Aqlan is an assistant professor of Industrial Engineering at The Pennsylvania State University, The Behrend College. He received his PhD in Industrial and Systems Engineering form The State University of New York at Binghamton in 2013. He has industry experience with IBM Corporation and Innovation Associates Company. His research interests include manufacturing education, simulation and automation, process improvement, ergonomics, supply chain, and cyberlearning. He has published more than 115 peer-reviewed research articles in reputed conferences and journals and received multiple best paper awards. Aqlan also holds 7 U.S. patents/patent applications and is the recipient of two NSF grants $(\$ 800 \mathrm{~K})$ and several internal and in-kind grants $(\$ 30 \mathrm{M})$. He has received numerous awards and honors including the Schreyer Institute for Teaching Excellence Award, Industrial Engineering and Operations Management Young Researcher Award, School of Engineering Distinguished Award for Excellence in Research, Council of Fellows Faculty Research Award, IBM Vice President Award for Innovation Excellence, IBM Lean Recognition Award, Graduate Student Award for Excellence in Research, and Outstanding Academic Achievement in Graduate Studies. He was recently named 40 Under 40: Class of 2019 by the Erie Reader. His projects and achievements have been recognized by U.S. Senators and Representatives. Aqlan is a member of ASEE, ASQ, SME, and IEOM. He is also a senior member of IISE and has served as president of IISE Logistics and Supply Chain Division, co-founder of IISE Modeling and Simulation Division, director of IISE Young Professionals Group, founder and faculty advisor of IISE Behrend Chapter, faculty chair of IISE Northeast Conference, and track chair in IISE Annual Conference. He currently serves as IISE Vice President of Student Development and holds a seat on IISE Board of Trustees. He also serves on IISE Technical Operations Board and leads IISE Cup initiative, which is an international competition to recognize organizations for innovative and effective implementation of industrial and systems engineering principles and practices that deliver exemplary business performance improvement. 


\title{
Teaching Science Using Dye-sensitized Solar Cells Kit
}

\begin{abstract}
In this paper, we discuss the working principles of dye-sensitized solar cells (DSSCs) and how to use DSSCs kit to teach science. Three high school teachers were trained to fabricate DSSCs as part of an ongoing NSF RET program. The materials and equipment used for producing DSSCs are basic, and a standard procedure was formulated for the work to be replicated in a regular classroom. DSSCs were constructed using fruit juices from blackberry, raspberry, mulberry, blueberry, and strawberry. The absorption spectra of fruit dyes, along with food dyes, were examined in contrast to the solar spectrum. Teachers demonstrate the working principle of DSSCs and integrate handson activities into the K-12 curriculum. As the outcome, students should be able to (1) explain how a dye-sensitized solar cell converts sunlight into electricity; (2) design and build a dye-sensitized solar cell from basic components; (3) maximize efficiency of their solar cells using various fruit dyes; and (4) measure the voltage and current output of DSSCs in comparison with silicon solar cells. Data collected from implementing the developed curriculum in high school classrooms is discussed and plans of both formative and summative assessment are presented.
\end{abstract}

\section{Introduction}

In the late 1960s it was discovered that illuminated organic dyes can generate electricity at oxide electrodes in electrochemical cells. In an effort to understand and simulate the primary processes in photosynthesis the phenomenon was studied at the University of California at Berkeley with chlorophyll extracted from spinach (bio-mimetic or bionic approach). On the basis of such experiments electric power generation via the dye sensitization solar cell (DSSC) principle was demonstrated and discussed in 1972.

A modern DSSC is composed of three main components: a photoanode, an electrolyte, and a counter electrode. The photoanode is made of a mesoporous, n-type semiconductor (e.g., $\mathrm{TiO}_{2}$, $\mathrm{SnO}_{2}$, and $\mathrm{ZnO}$ ) deposited on a transparent conductive oxide (TCO) glass substrate; likewise, the counter electrode is made of a platinum-coated TCO glass. The semiconductor is configured at a nanoscale level, including the interconnection of nanoparticles, electrospun nanofibers, and their composites [1,2]. The nanoscale arrangement tremendously enhances the surface area, which could accommodate a monolayer of dye sensitizers or coating of quantum dots. The electrolyte containing a redox couple (typically, $\mathrm{I}^{-} / \mathrm{I}_{3}{ }^{-}$) sets up a conduit between the photoanode and the counter electrode. Unlike conventional semiconductor solar cells, the DSSC is unique in terms of dye sensitizers serving as the electron generator and do not interfere with charge transport [3, 4].

Figure 1 shows the schematic and working principle of the DSSCs [5]. When exposed to the sunlight, dye molecules get excited and inject electrons into the conduction band of the 
semiconductor. The photogenerated electrons diffuse all the way to the conductive glass substrate, and electric work is accomplished through an external circuit. The electrons are harvested by the counter electrode, whereas platinum catalyst activates the redox reduction in the electrolyte transforming $\mathrm{I}_{3}{ }^{-}$to $\mathrm{I}^{-}$. The reducing species $\left(\mathrm{I}^{-}\right)$in turn is transported to the oxidized dye molecules so that the dye gets regenerated to complete the cycle.

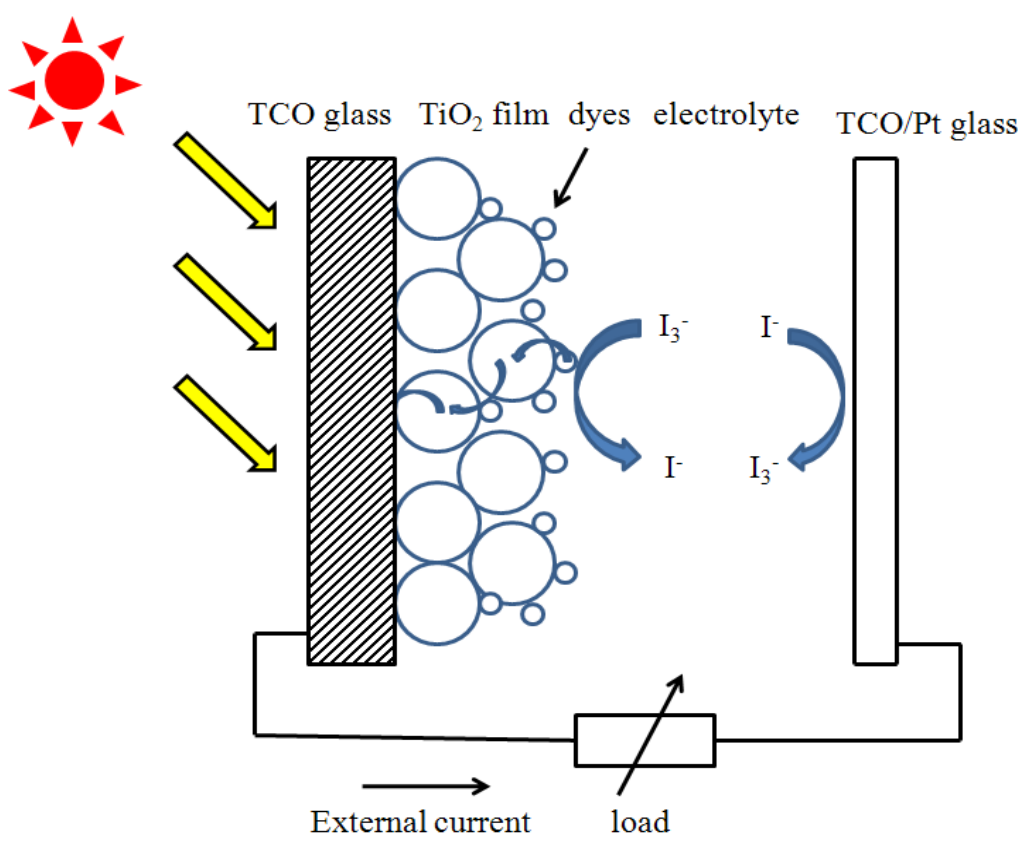

Figure 1. Schematic of dye-sensitized solar cells [5].

\section{Construction}

The procedure of fabricating a DSSC is simple and can be carried out under ambient conditions. Firstly, the fluorine-doped tin oxide (FTO) glass is cleaned with detergent to remove both contaminants and fingerprints. Subsequently, the cleaned glass is subjected to ultrasonication with the deionized water, acetone, and isopropyl alcohol. The clean substrate is then dried with compressed nitrogen gas and subjected to $\mathrm{UV}-\mathrm{O}_{3}$ treatment. $\mathrm{The}^{\mathrm{TiO}} \mathrm{O}_{2}$ photoanode comprises three major layers: blocking layer (also known as compact layer), transparent layer, and scattering layer. The following procedure is adopted to produce these layers: i) Titanium diisopropoxide bis(acetylacetonate) solution (with anhydrous ethanol) is deposited on the clean FTO substrate and is subjected to sintering at a temperature above $400{ }^{\circ} \mathrm{C}$ to form a compact, electron blocking layer. ii) Then, the transparent layer of $\mathrm{TiO}_{2}$ nanocrystalline $(10-15 \mu \mathrm{m})$ is screen-printed. iii) to increase the backscattering, a reflective layer at about $5 \mu \mathrm{m}$ thick is deposited on the transparent layer; the film is further treated with an aqueous solution of $\mathrm{TiCl}_{4}$ to increase the roughness. As the last step, the film is loaded with dye sensitizers to make the photoanode ready for use. Similar to the photoanode, the counter electrode is made by spaying Pt catalyst using atomizer on the FTO glass. Finally, both electrodes are sandwiched and sealed with $60 \mu \mathrm{m}$ plastic (Surlyn, Dupont), followed by the injection of electrolyte through the reserved channel. Figure 2 shows the assembly of the DSSC components. 


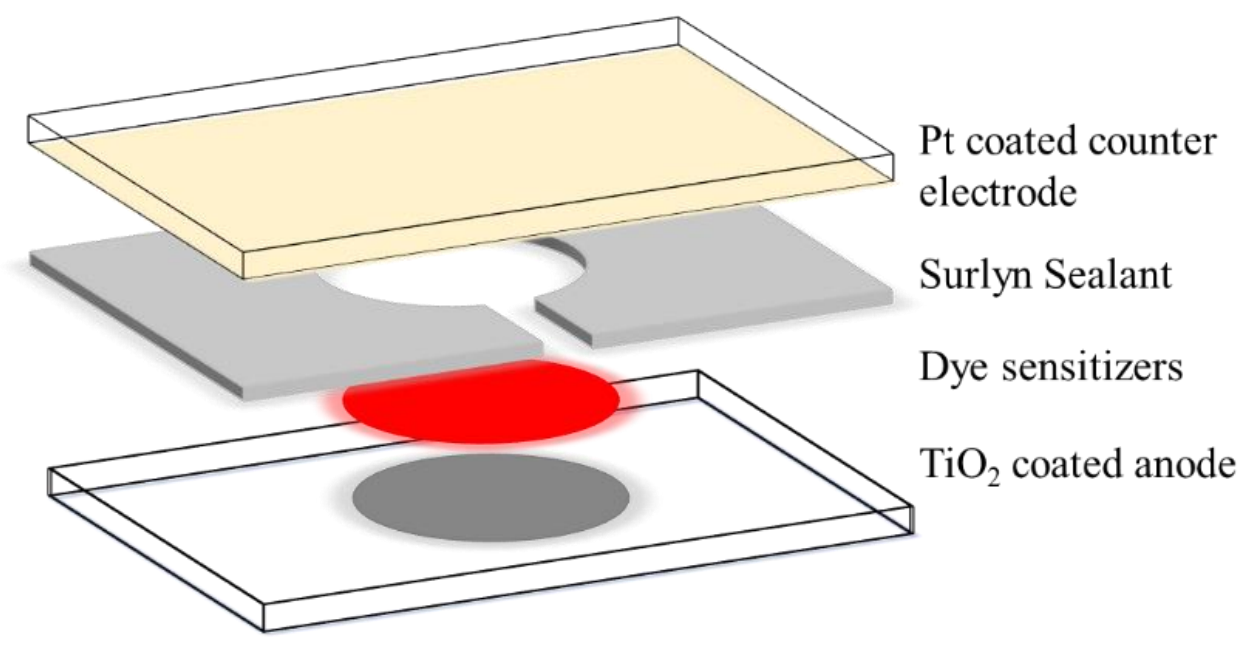

Figure 2. Schematic of DSSC device assembly.

The following steps convert in a DSSC photons (light) to current. The incident photon is absorbed by $\mathrm{Ru}$ complex photosensitizers adsorbed on the $\mathrm{TiO}_{2}$ surface. The photosensitizers are excited from the ground state $(\mathrm{S})$ to the excited state $\left(\mathrm{S}^{*}\right)$. The excited electrons are injected into the conduction band of the $\mathrm{TiO}_{2}$ electrode. This results in the oxidation of the photosensitizer $\left(\mathrm{S}^{+}\right)$.

$$
\begin{aligned}
& \mathrm{S}+\mathrm{h} v \rightarrow \mathrm{S}^{*} \\
& \mathrm{~S}^{*} \rightarrow \mathrm{S}^{+}+\mathrm{e}^{-}
\end{aligned}
$$

The injected electrons in the conduction band of $\mathrm{TiO}_{2}$ are transported between $\mathrm{TiO}_{2}$ nanoparticles with diffusion toward the back contact (TCO). And the electrons finally reach the counter electrode through the circuit. The oxidized photosensitizer $\left(\mathrm{S}^{+}\right)$accepts electrons from the $\mathrm{I}^{-}$ion redox mediator leading to regeneration of the ground state $(\mathrm{S})$, and two $\mathrm{I}^{-}$Ions are oxidized to elementary Iodine which reacts with $\mathrm{I}^{-}$to the oxidized state, $\mathrm{I}_{3}^{-}$.

$$
\mathrm{S}^{+}+\mathrm{e}^{-} \rightarrow \mathrm{S}
$$

The oxidized redox mediator, $\mathrm{I}_{3}{ }^{-}$, diffuses toward the counter electrode and then it is reduced to $\mathrm{I}^{-}$ ions.

$$
\mathrm{I}_{3}^{-}+2 \mathrm{e}^{-} \rightarrow 3 \mathrm{I}^{-}
$$

The efficiency of a DSSC depends on four energy levels of the component: the excited state (approximately LUMO) and the ground state (HOMO) of the photosensitizer, the Fermi level of the $\mathrm{TiO}_{2}$ electrode and the redox potential of the mediator $\left(\mathrm{I}^{-} / \mathrm{I}_{3}{ }^{-}\right)$in the electrolyte [6].

\section{Methodology}

\section{Solar Cell Unit Pre-Assessment}

This short assessment of the nice multiple-choice problems is designed to help students identify their prior knowledge about solar cells and the topics they might want to review.

1. What are the types of energy into which efficient solar cells can convert light?
a. Chemical
b. Electrical 

c. Heat
d. Both $\mathrm{A}$ and $\mathrm{B}$
e. Both B and C
f. All the above

2. Which of the following compounds allow plants to absorb light effectively?
a. Titanium dioxide
b. Chlorophyll
c. Plant pigments
d. Both B and C
e. Both $\mathrm{A}$ and $\mathrm{C}$
f. None of the above

3. How does the size of a semiconductor's band gap affect the wavelength of light it absorbs?
a. The larger the band gap, the shorter the wavelength of light needed to excite an electron in the semiconductor.
b. The larger the band gap, the longer the wavelength of light needed to excite an electron in the semiconductor.
c. The wavelength of light that a semiconductor absorbs is unaffected by the size of the band gap.

4. Assuming that you are presented with the same amount of each, what form of a semiconductor has the largest surface area?
a. Bulk silicon (i.e. a thin piece of silicon)
b. Silicon nanoparticles
c. They should have the same surface area.

5. Which of the following accounts for the most energy use in a home?
a. Electronics
b. Heating and cooling rooms
c. Water heating
d. Refrigeration

6. Which renewable energy source provides the most energy in the US?
a. Wind
b. Solar
c. Geothermal
d. Wood-derived fuels

7. Which energy source releases the most climate-altering carbon pollution?
a. Oil
b. Coal
c. Natural gas
d. Solar 
8. What does the word photovoltaic mean?
a. Sun-Powered
b. Light-cells
c. Light-Electricity
d. Solar-Energy

9. What are the most common photovoltaic cells used today?
a. Organic cells
b. Polymer Cells
c. Plastic Cells
d. Crystalline silicon cells

\section{Experiment and Procedures}

\section{Materials:}

- Anode Cell with Titania layer

- Cathode Cell with copper tape

- Fresh Berries

- Plastic Pipette

- Iodide Solution

- Multimeter with millivolt and microamp settings

- Pencil

- Plastic Bag

- Light Source

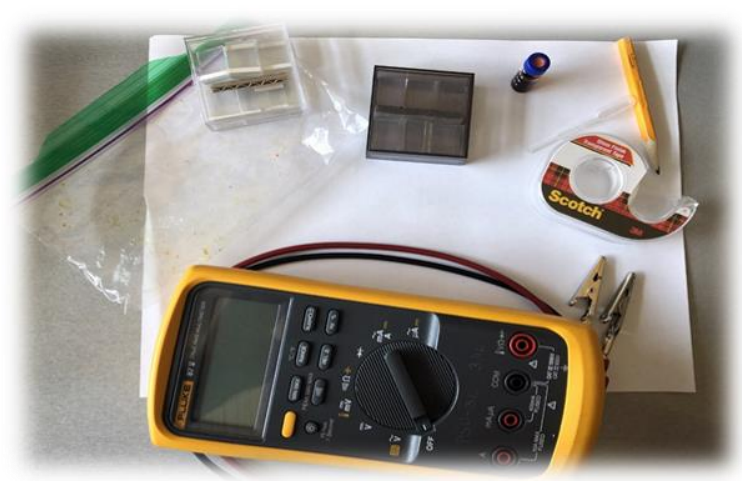

Briefly, the cathode is scrubbed with pencil lead and the anode is soaked in fruit juice; the two slides are stacked together and wrapped in transparent tape; and lastly, a drop of electrolyte is introduced between the two glass slides to create a solar cell. Up to 6 cells are then connected to create a solar panel, which hopefully produces enough power to glow a small LED bulb when placed under sunlight.

\section{Procedure:}

Step 1: Prepare the dye by placing a berry in a plastic bag and seal. Using your hands, squeeze the berry to completely break it apart. Be careful not to poke any holes in the bag.
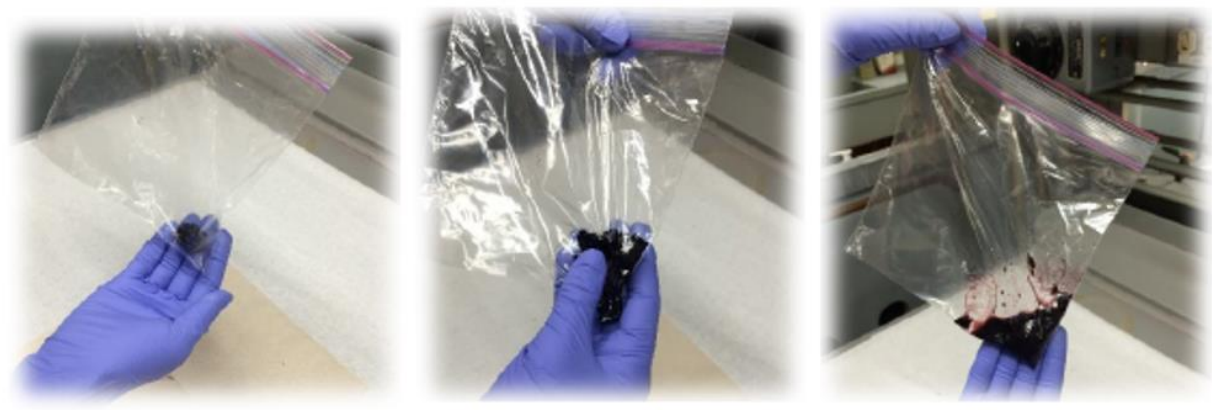
Step 2: Take a piece of anode and place it into the bag containing the juice tape side down. Let the anode soak for 5 minutes so that the layer of Titania is completely covered. Be sure that the glass is completely covered. The white Titania should turn completely purple so there is no white left. Note: The darker the better.

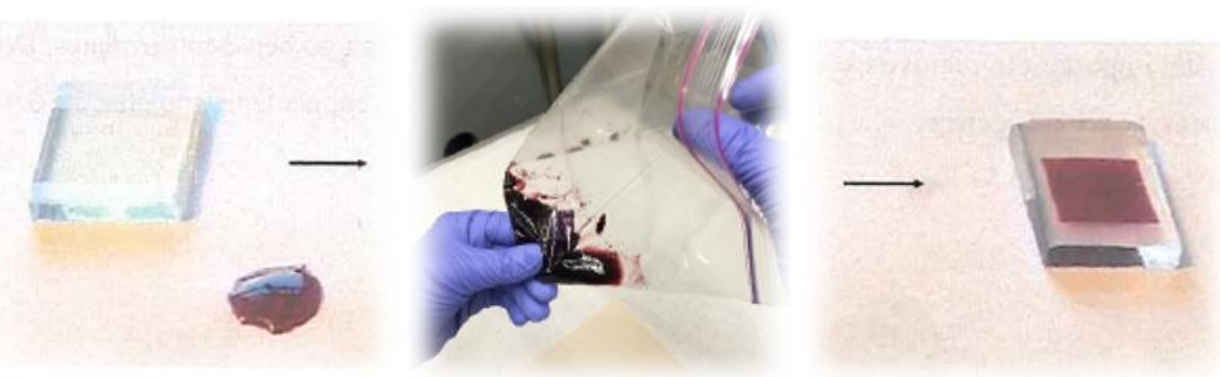

Step 3: While the anode is soaking, take a piece of cathode and place it on your desk with the taped(conductive) side facing up. Start from one corner and slowly scribble diagonally with pencil to cover the exposed surface with graphite. If you scribble on the back side, it won't work! For best results, apply another layer of graphite by scribbling in another direction, as shown. Remove excess graphite with a facial tissue.

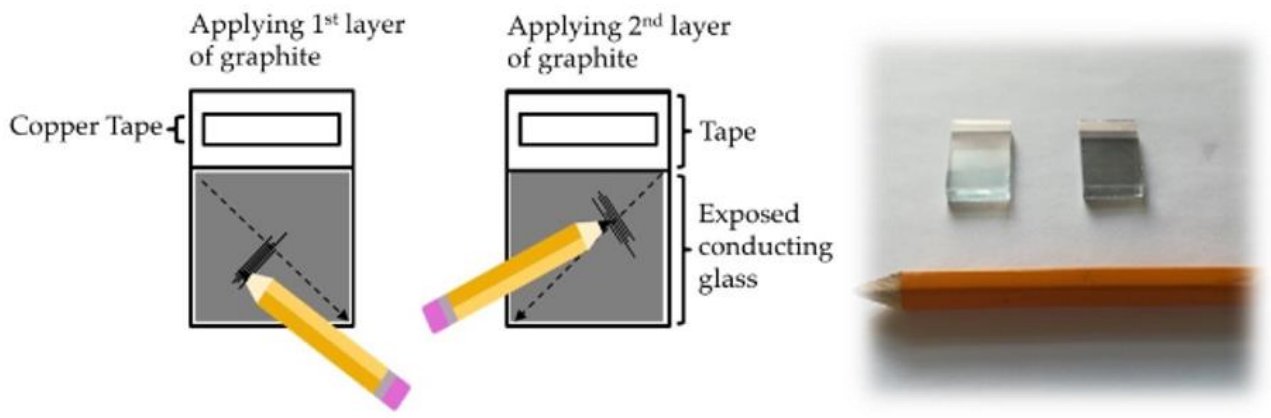

Step 4: Remove the anode from the bag using tweezers after 5 minutes of soaking and rinse in a beaker of DI water. This will remove excess fruit juice and other deposits from the surface. Take the plate out of the water, gently dab it with tissue paper to remove water. Do not wipe the dye/Titania or it will come off.
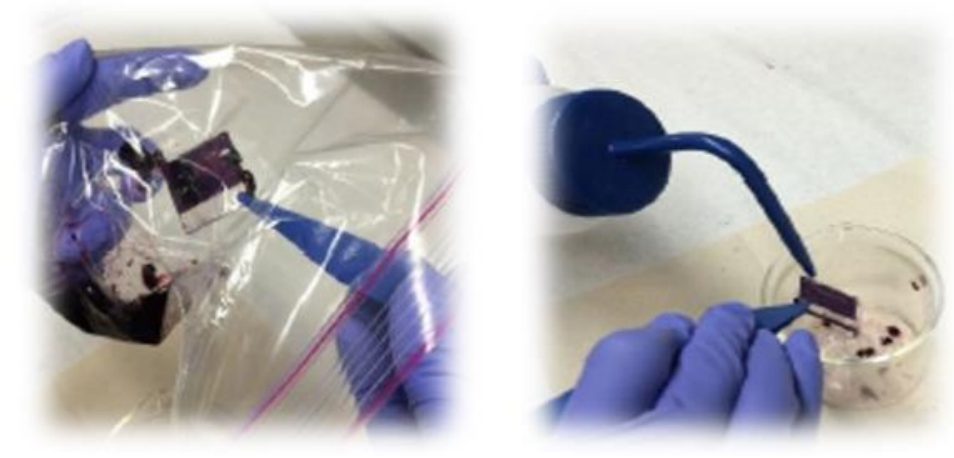

Precautions: Avoid touching the conductive surface and Titania layer with fingers as it may cover it with a layer of grease. Moisture degrades solar cell performance. Hence, the anode must be dried properly. Don't remove the protective tape. Applying the juice for longer time (5 mins waiting).

Step 5: Add one drop of iodide solution to the anode using a pipette. 

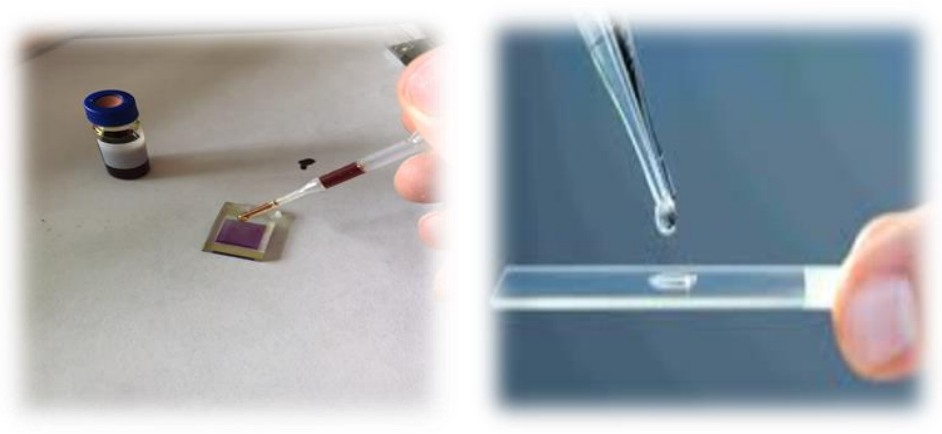

Step 6: Put the anode and cathode slides together, as shown. The colored Titania on the anode should touch the graphite layer on the cathode, and the two taped surfaces should be on the opposite ends.
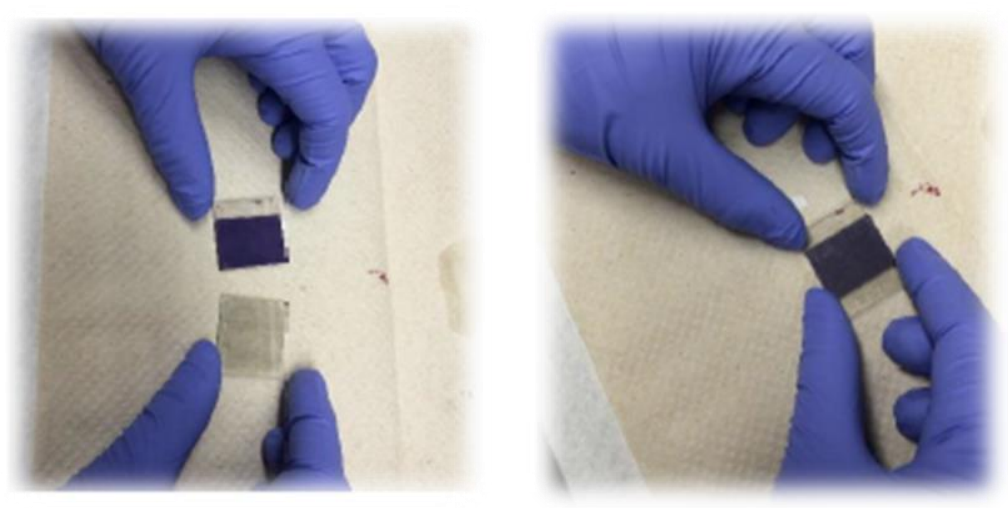

Step 7: Remove a small piece of tape from the dispenser and use it to tightly wrap the two slides such that they don't move.

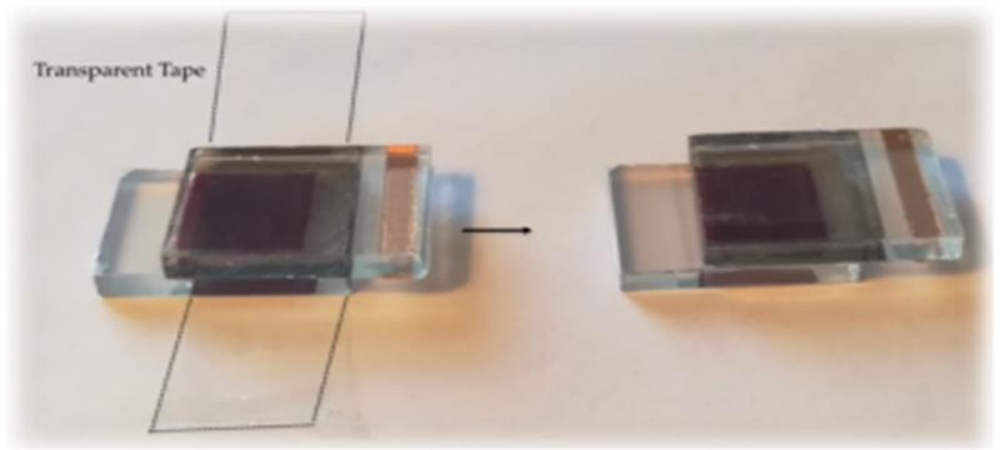

Precautions: Upon taping, the two glass slides should not move. Don't remove the protective tape from cathode and anode terminals.

Step 8: Remove excess iodide solution from the edges using a facial tissue. At this point, carefully remove the two protective tapes from the anode and cathode terminals. Remove the white paper carefully from the cathode terminal but don't remove the copper tape underneath. The device is now ready. 

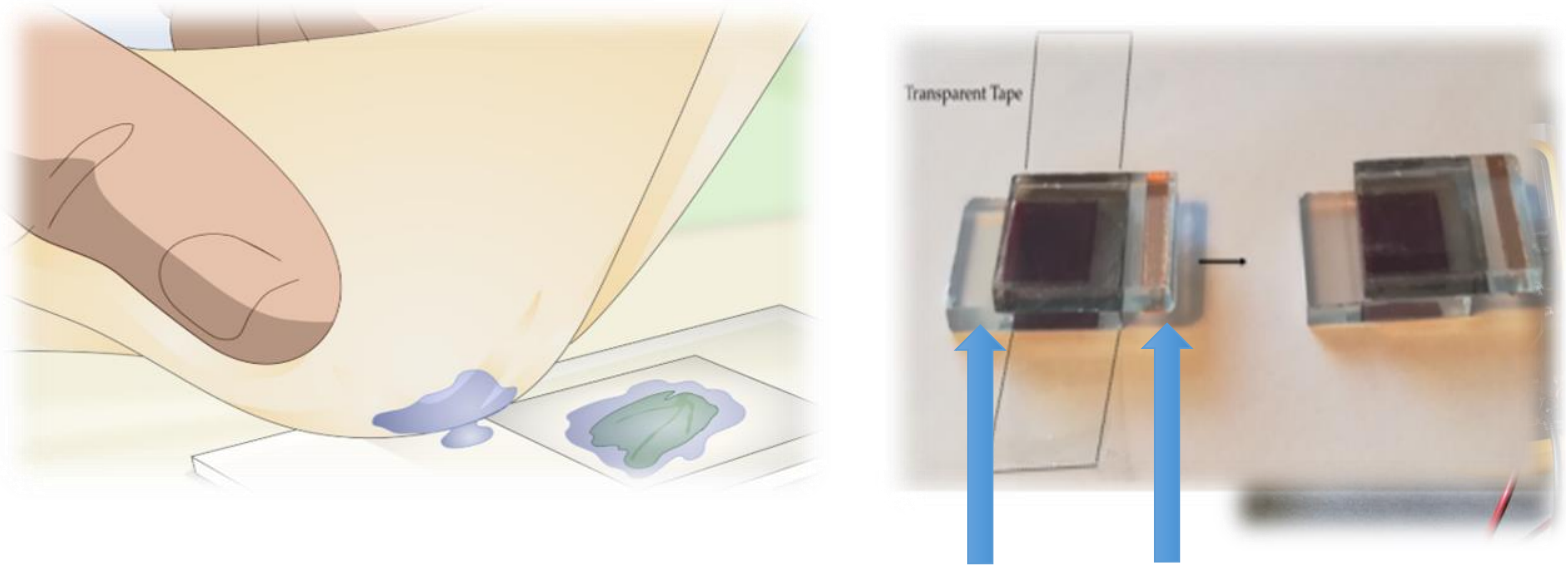

Step 9: To test your solar cell, clip one end of the multimeter using an alligator clip to one of the overhanging pieces of glass. Use the second alligator clip of the multimeter and clip it to the other piece of overhanging glass.

Step 10: Make sure to plug the red multimeter probe into the $\mathrm{mA} \mu \mathrm{A}$ slot and the black multimeter probe to the COM slot. Switch the multimeter setting to $\mu \mathrm{A}$ for microamps and DC for direct current. An average reading in full sunlight is around $650 \mu \mathrm{A}$. In the data table, record your current value with the proper units.

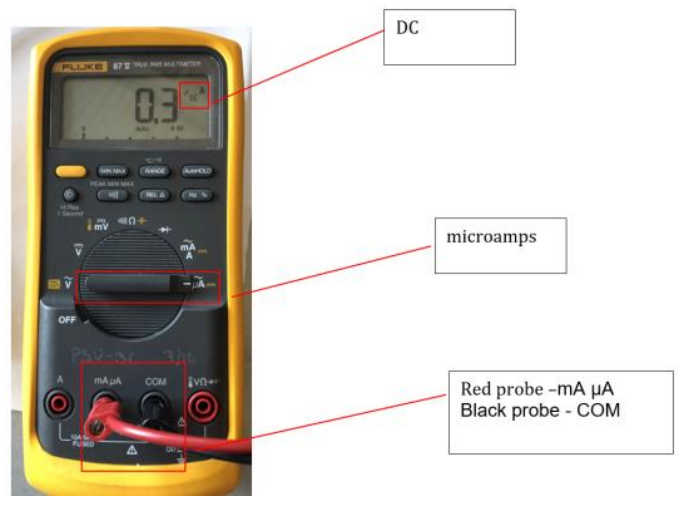

Precautions: If the reading is negative, this just means the meter is measuring electricity flowing in the opposite direction. Simply switch to which electrode the alligator clips are attached and the reading will become positive.

Step 11: Make sure to plug the red multimeter probe into the $\mathrm{V}$ slot and the black multimeter probe to the COM slot. Switch the multimeter setting to $\mathrm{mV}$ for millivolts and DC for direct current. An average reading in full sunlight is around $350 \mathrm{mV}$. In the data table, record your current value with the proper units.

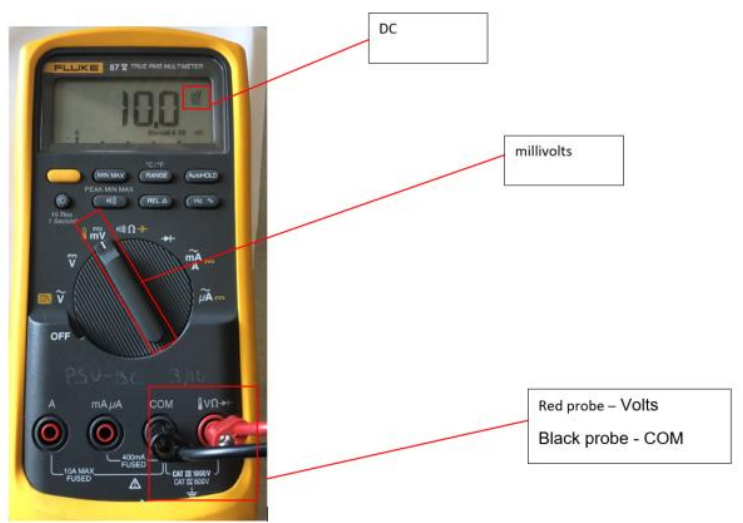

Step 12: Collect the voltage and current for each dye from each group and enter them into your table. Use the voltage and current to calculate the power $(\mathrm{P}=\mathrm{IV})$ for each cell. Use this data to make a single bar graph to represent all the different dyes and mixed dyes. 


\section{Plan of Assessment}

Assessment is implemented in the class and after the class. Some of the sample questions of formative assessment are provided below.

\begin{tabular}{|l|l|l|l|}
\hline \multicolumn{1}{|c|}{ Term } & Definition & \multicolumn{1}{|c|}{ Term } & Definition \\
\hline Solar Cell & & Catalyst & \\
\hline Anode & & Cathode & \\
\hline Electrolyte & & Nanoparticle & \\
\hline Electrical Circuit & & Photovoltaic & \\
\hline Semiconductor & & $\begin{array}{l}\text { Open Circuit } \\
\text { voltage }\end{array}$ & \\
\hline Short Circuit & & Covalent Bond & \\
Current & & $\begin{array}{l}\text { Electrical } \\
\text { Terminal }\end{array}$ & \\
\hline Wavelength & & Electron & \\
\hline Electrode & & & \\
\hline Electrical Power & & & \\
\hline
\end{tabular}

\section{Solar Cell Information Sheet}

1. What is the range of visible wavelengths?

2. What is the relationship between power, voltage, and current?

3. What type of relationship exists between output power and wavelength in the solar cells?

4. What is/are the catalyst(s) in a dye sensitized solar cell?

5. Explain why different fruits/vegetables give different power outputs in solar cells?

6. What happens to solar cell performance under different light intensities?

\section{Solar Cell Post-Assessment: Short Answer/Extended Response}

1. Make a diagram comparing and contrasting dye-sensitized solar cells and conventional silicon solar cells.

2. Explain why different fruits/ vegetables give different performance.

3. During solar cell operation, does it matter which side is facing the sun? Why? 


\section{Exit Ticket}

\begin{tabular}{|l|l|l|}
\hline What did we do? & Why did we do it? & What did I learn today? \\
\hline & & \\
\hline How can I apply it? & What questions do I still have about it? \\
\hline & \\
\hline
\end{tabular}

\section{Summative Assessment Plan}

1. Students will research the function of the DSSC and write a summary of their information.

- What are two types of solar cells?

- Definition of terms (List)

- Where are solar cells used?

- What are the benefits of solar cells?

- Venn Diagram to compare, and contrast the information about solar cells

- What are the wavelengths used for solar cells?

2. The students will fabricate a DSSC for each separate dye using the experimental procedure.

- The students put the graphite on the cathode.

- The students apply the dye to the anode.

- The students construct the solar cell and applies the iodine.

3.The students will measure the voltage and current for each solar cell and create and calculate power.

- The students should measure the open circuit voltage using a multimeter.

- The students should measure the short circuit current.

- The students will calculate the power for their cell using their voltage and current measurements.

4. The students will analyze the data using the class data from step 3.

- The students will graph the class data (Power versus dye type)

\begin{tabular}{|c|c|c|c|}
\hline \multicolumn{5}{|c|}{ Dye-Sensitized Cell with graphite coated anode } \\
\hline Dye type & $\begin{array}{c}\text { Open Circuit Voltage } \\
\text { V, (volts) }\end{array}$ & $\begin{array}{c}\text { Short Circuit Current } \\
\text { I, (milliamps) }\end{array}$ & $\begin{array}{c}\text { Power (watts) } \\
\text { P = V x I }\end{array}$ \\
\hline A & & & \\
\hline B & & & \\
\hline C & & & \\
\hline D & & & \\
\hline AB & & & \\
\hline AC & & & \\
\hline AD & & & \\
\hline BC & & & \\
\hline BD & & & \\
\hline CD & & & \\
\hline
\end{tabular}


5. The students will fabricate a DSSC using their same dye and a candle instead of graphite.

- The students will assemble the DSSC using candle to coat cathode (instead of graphite)

- The students will use Different types of dye to coat the $\mathrm{TiO}_{2}$ on the anode.

- The students will measure voltage and current for each DSSC.

- The students will collect the data for each different DSSC and enter it into the table.

6. The students will use their solar cells to compare series and parallel power sources.

7. The students will analyze, answer exercise questions and present their experiment to the class.

- The students will answer the following exercise questions.

- Draw solar cell diagram and show the various components, such as anode, cathode, Copper tape, Titania layer, Anthocyanin layer, graphite layer, electrolyte layer, positive and negative terminals.

- Draw a diagram of a solar cell under operation and show the following: light absorption by the anthocyanin dye; electron flow from anthocyanin through Titania layer into the negative terminal and out of the solar cell; the flow of electrons from outside into the cathode terminal; flow of electrons from the graphite layer back to the dye through the iodine solution.

- How does the output voltage and current change on creating a solar panel?

- Explain why different fruits/ vegetables give different performance?

- During solar cell operation, does it matter which side is facing the sun? Why?

- What happens to solar cell performance under different light intensities, for instance, direct sunlight, indirect sunlight, light inside the room.

- The students will give a summary of their research of DSSC's.

- The students will graph the data using current vs voltage using a line graph.

- The students will graph dye verses voltage and current using a bar graph.

\section{Standards}

I. Curriculum Standard Pennsylvania Department of Education Standard Aligned Systems Standards (PDE SAS)

a. 3.4.10.A2 Interpret how systems thinking applies logic and creativity with appropriate comprises in complex real-life problems.

b. 3.4.10.B4 Recognize that technological development has been evolutionary, the result of a series of refinements to a basic invention.

c. 3.4.10.C1 Apply the components of the technological design process.

d. 3.4.10.C2 Analyze a prototype and/or create a working model to test a design concept by making actual observations and necessary adjustments.

e. 3.4.10.D1 Refine a design by using prototypes and modeling to ensure quality, efficiency, and productivity of a final product.

f. 3.4.10.E7 Evaluate structure design as related to function, considering such factors as style, convenience, safety, and efficiency 
II. Next Generation Science Standards (NGSS)

a. MS-ETS1- Engineering Design Undertake a design project, engaging in the design cycle, to construct and/or implement a solution that meets specific design criteria and constraints. (MS-PS1-6)

b. Develop a model to generate data to test ideas (MS-ETS1-4)

III. Ohio Learning Standard. C.IM.1: Chemical reaction

IV. Common core Math Standards Grade 9-12

a. Visualize relationships between two-dimensional and three-dimensional objectsCCSS.MATH.CONTENT.HSG.GMD.B.4

b. Make formal geometric constructions with a variety of tools and methods CCSS.MATH.CONTENT.HSG.CO.D.12

\section{Conclusions}

This paper presented a study by two high school teachers to science to high school students using solar cells. Students will study the working principle of solar cells, construct dye-sensitized solar cells (DSSCs) in lab and test the cell performance using basic equipment. Students will learn how a dye-sensitized solar cell converts light waves into electricity; design and build a dye-sensitized solar cell from basic components and different fruit dye; refine their solar cell design through the comparison of various fruit dyes; and evaluate a dye-sensitized solar cell's performance based on wavelength absorption and voltage, current, and power output. In addition, students will present their research study, conduct experiment, gather data, analyze data, and generate conclusion in their report.

Our goal of the dye sensitized solar cells is to gather information from our students' experiences. The data from the assessments will be summarized. The measured data will be accumulated and analyzed. We will see what improvements can be made to the implementation and use them in the future.

\section{Acknowledgement}

This research is funded by the National Science Foundation awards \#1711603. Any opinions, findings, or conclusions found in this paper are those of the authors and do not necessarily reflect the views of the sponsor. 


\section{References}

[1] J. W. Gong et al., "Characteristics of $\mathrm{SnO}_{2}$ nanofiber/TiO 2 nanoparticle composite for dyesensitized solar cells," (in English), AIP Advances, Article vol. 5, no. 6, p. 10, Jun 2015, Art no. 067134, doi: 10.1063/1.4922626.

[2] S. Sigdel et al., "Dye-Sensitized Solar Cells Based on Porous Hollow Tin Oxide Nanofibers," (in English), IEEE Transactions on Electron Devices, Article vol. 62, no. 6, pp. 2027-2032, Jun 2015, doi: 10.1109/ted.2015.2421475.

[3] J. Gong, K. Sumathy, Z. Zhou, and Q. Qiao, "Modeling of interfacial and bulk charge transfer in dye-sensitized solar cells," Cogent Engineering, vol. 4, no. 1, 2017 2017, Art no. Unsp 1287231, doi: 10.1080/23311916.2017.1287231.

[4] J. Gong, K. Sumathy, and J. Liang, "A simplified electrical model of the dye-sensitised photoelectrochemical cell," International Journal of Sustainable Energy, vol. 35, no. 1, pp. 75-87, 2016 2016, doi: 10.1080/14786451.2013.870176.

[5] J. W. Gong, J. Liang, and K. Sumathy, "Review on dye-sensitized solar cells (DSSCs): Fundamental concepts and novel materials," Renewable \& Sustainable Energy Reviews, vol. 16, no. 8, pp. 5848-5860, Oct 2012, doi: 10.1016/j.rser.2012.04.044.

[6] G. P. Smestad and M. Gratzel, "Demonstrating electron transfer and nanotechnology: A natural dye-sensitised nanocrystalline energy converter," Journal of Chemical Education, vol. 75, no. 6, pp. 752-756, Jun 1998, doi: 10.1021/ed075p752. 


\section{Appendix}

The current and voltage output is correlated to the spectrum absorption of the dye sensitizer. The standard procedure is to use a spectrophotometer (Varian Cary 300, Cary WinUV software version 3.00) is to measure the number of photons (the intensity of light) absorbed after it passes through sample solution. With the spectrophotometer, the amount of a known chemical substance (concentrations) can also be determined by measuring the intensity of light detected.
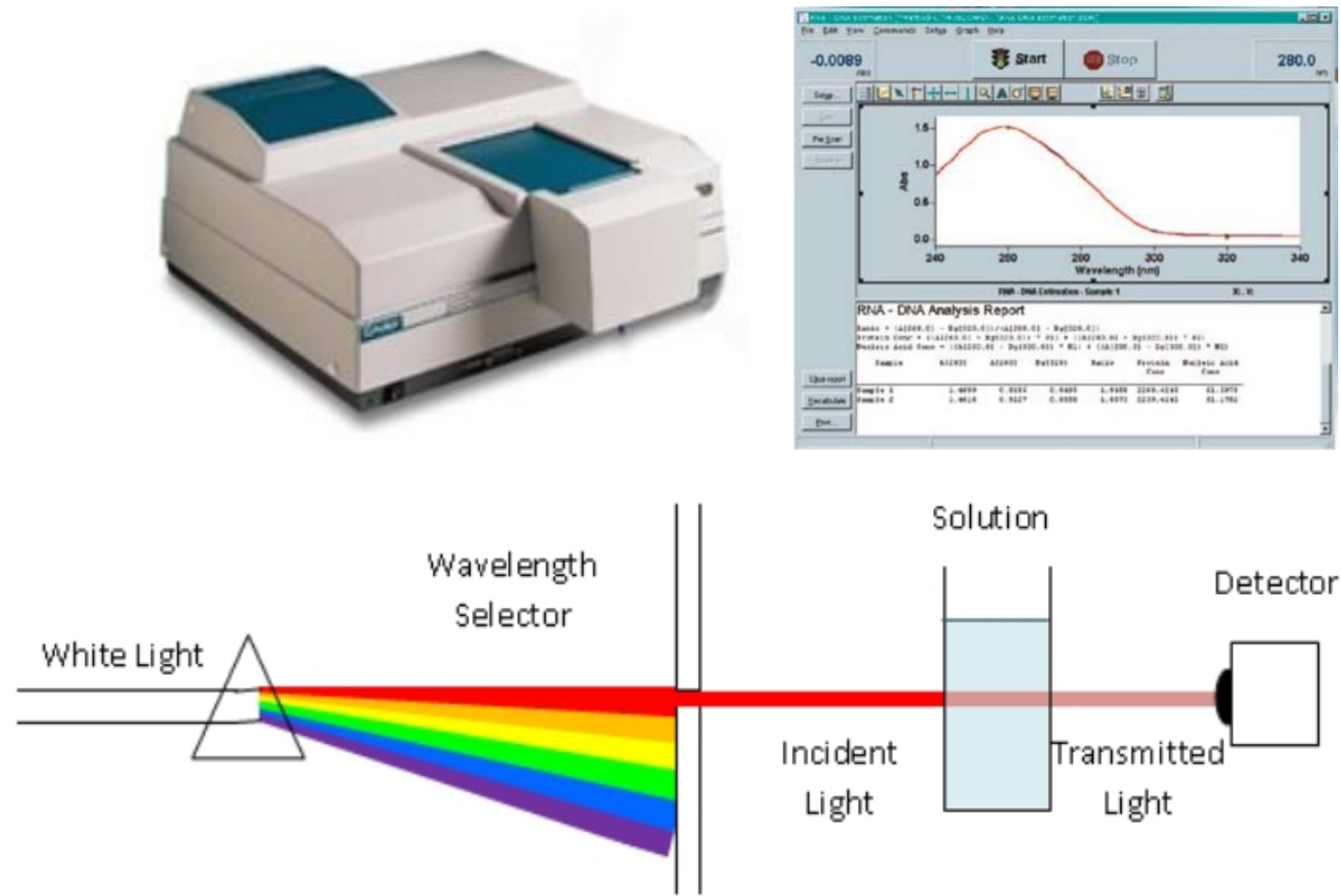

The differeno between the incident and transmitted light

indicates the absorbance

Table 1. DSSCs Power Chart for different Dyes

\begin{tabular}{|l|c|c|c|}
\hline \multicolumn{1}{|c|}{ Dye Type } & Voltage(V), $\mathbf{~ m V}$ & Current (I), mA & Power(P), mW \\
\hline blackberry & 436 & 0.892 & 0.389 \\
\hline blueberry & 405 & 0.600 & 0.243 \\
\hline strawberry & 400 & 0.360 & 0.144 \\
\hline raspberry & 416 & 0.670 & 0.279 \\
\hline blackberry-blueberry & 369 & 0.523 & 0.193 \\
\hline blackberry-strawberry & 375 & 0.590 & 0.221 \\
\hline blackberry- raspberry & 371 & 0.872 & 0.324 \\
\hline blueberry-strawberry & 336 & 0.316 & 0.106 \\
\hline blueberry-raspberry & 381 & 0.718 & 0.274 \\
\hline strawberry-raspberry & 392 & 0.454 & 0.178 \\
\hline
\end{tabular}


The pictures below show sample research activities and the following figures below show the results obtained from the different components for the solar cells.
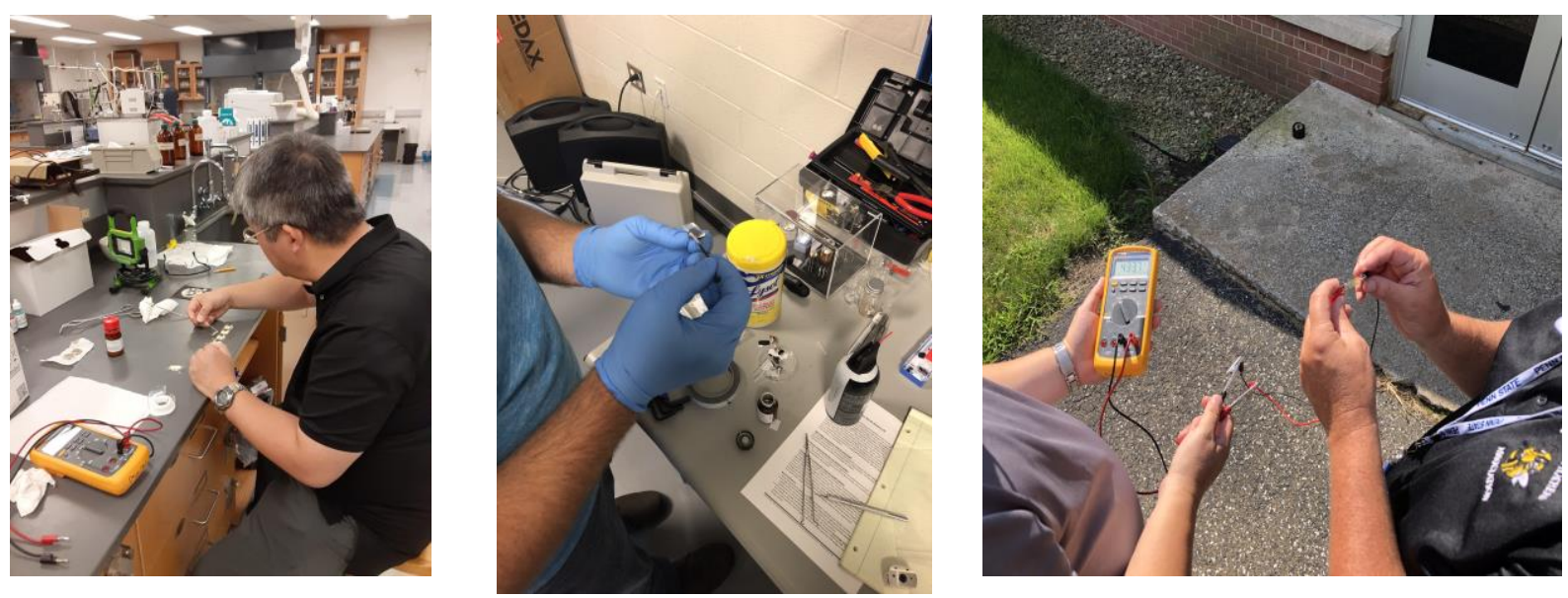

Black Berry: wavelength (515nm), absorption (0.512au)

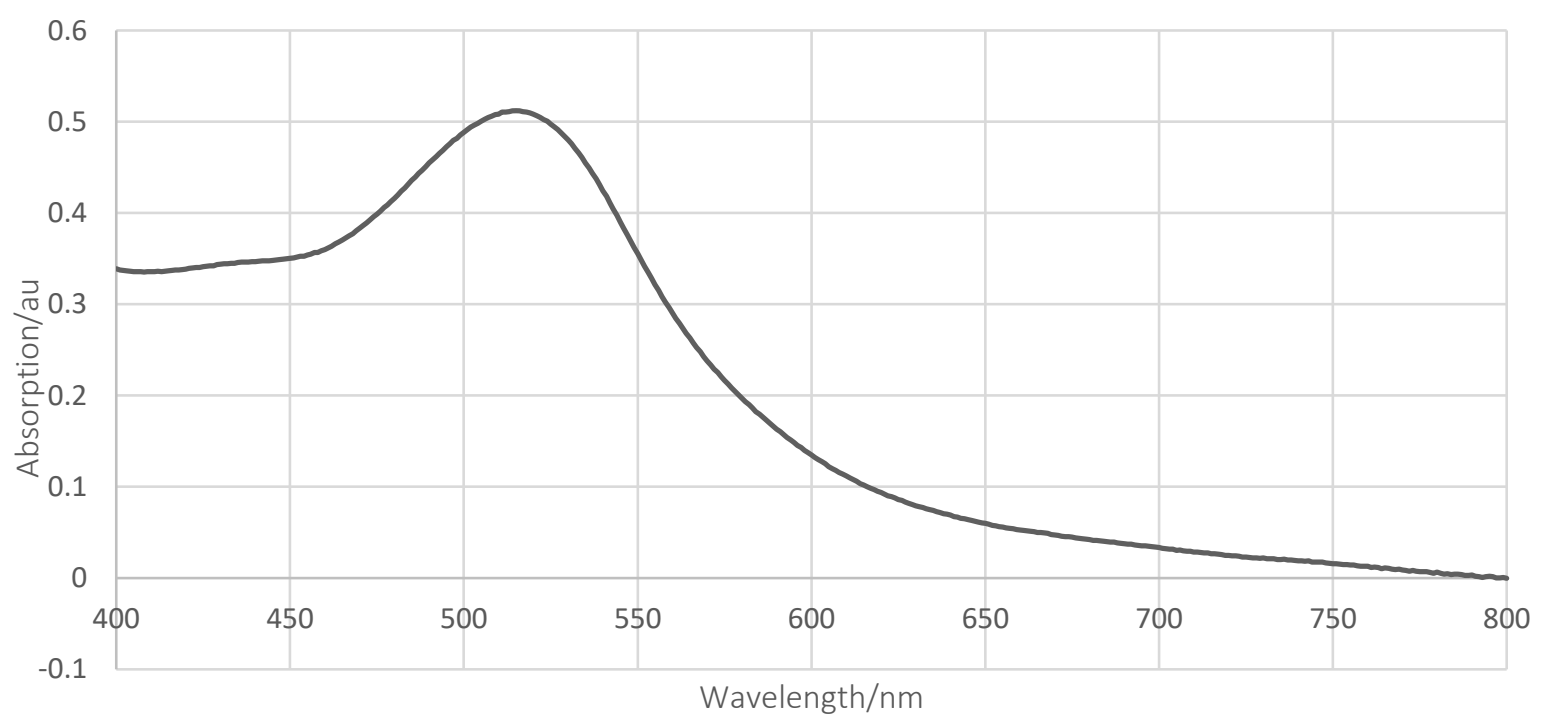



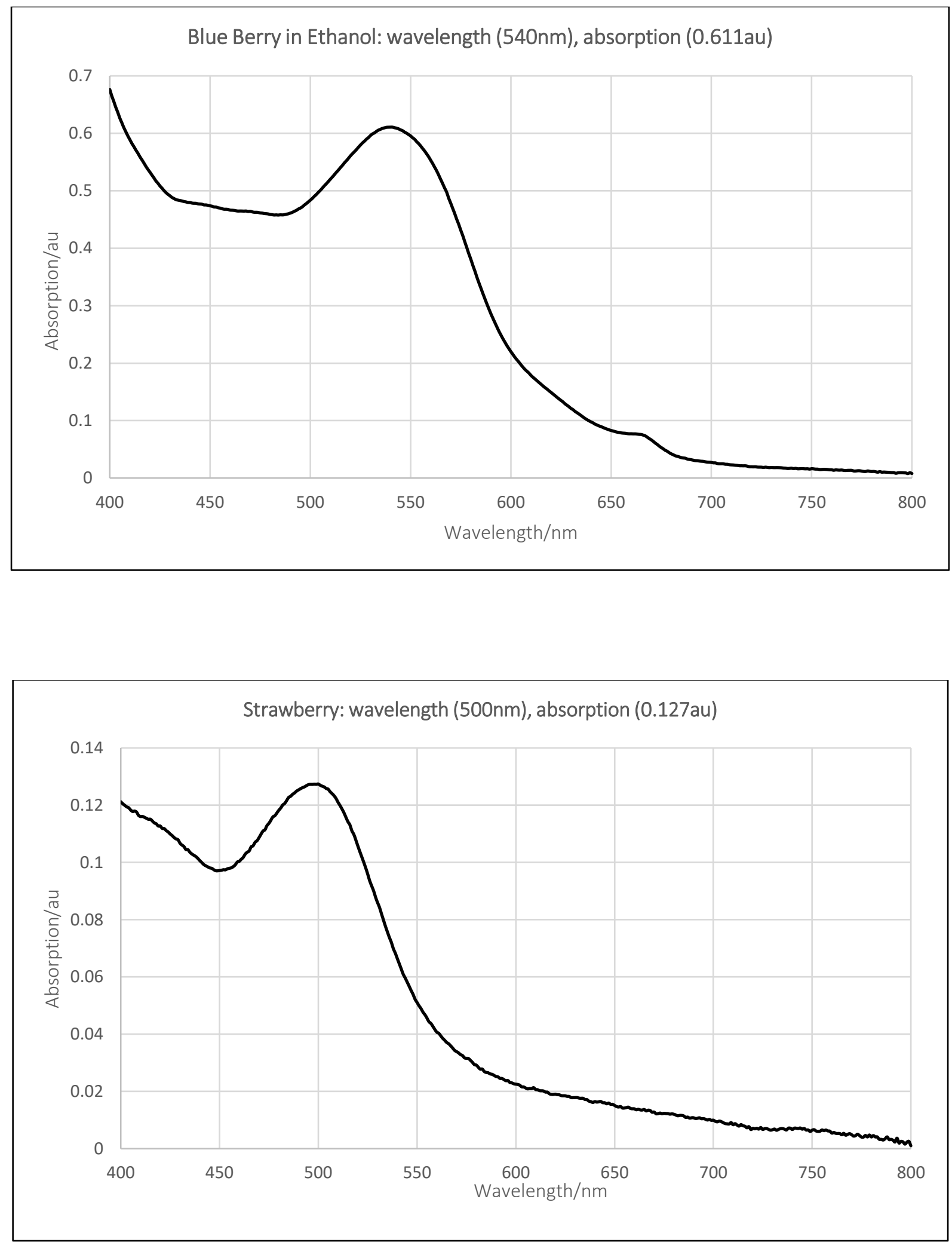

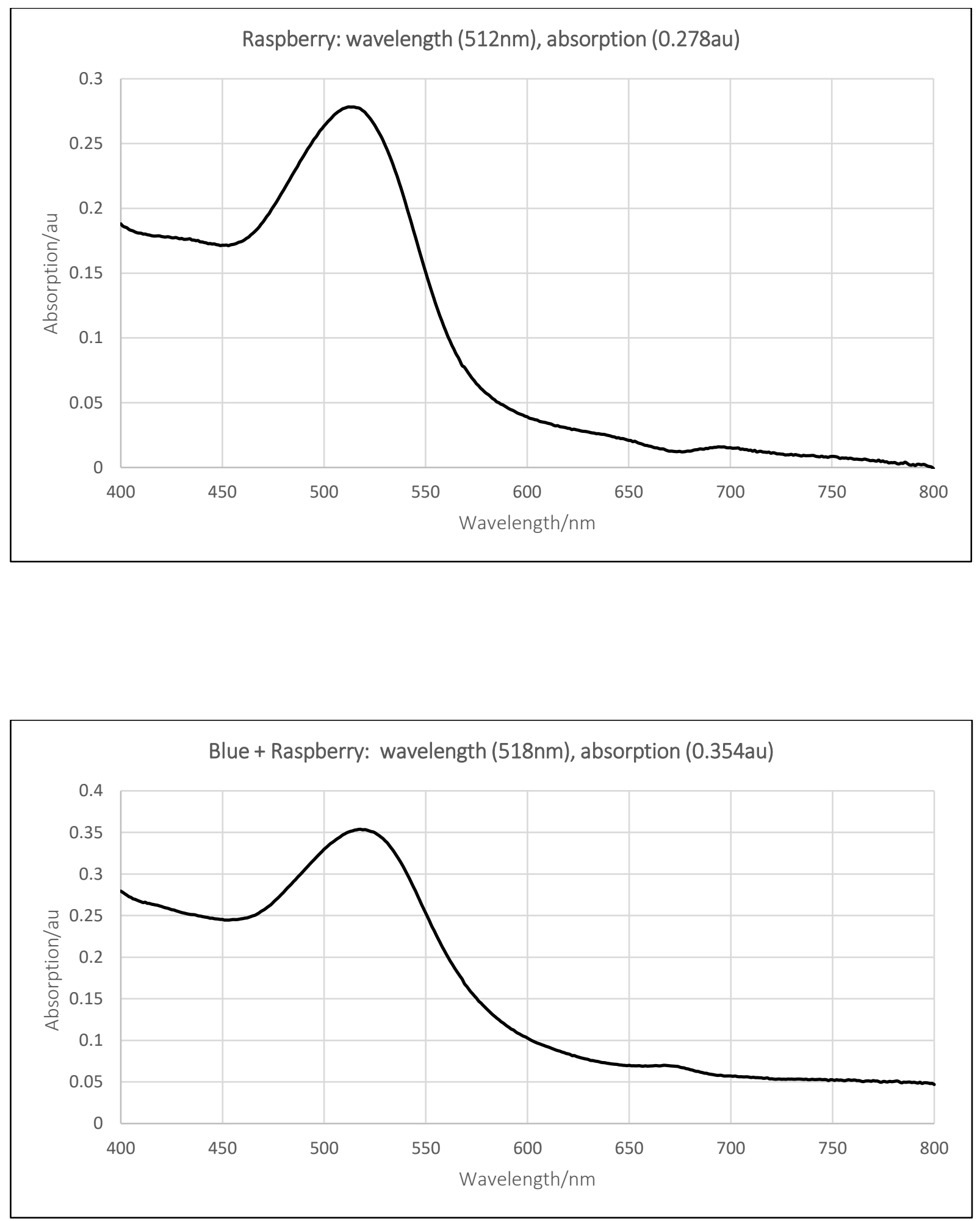

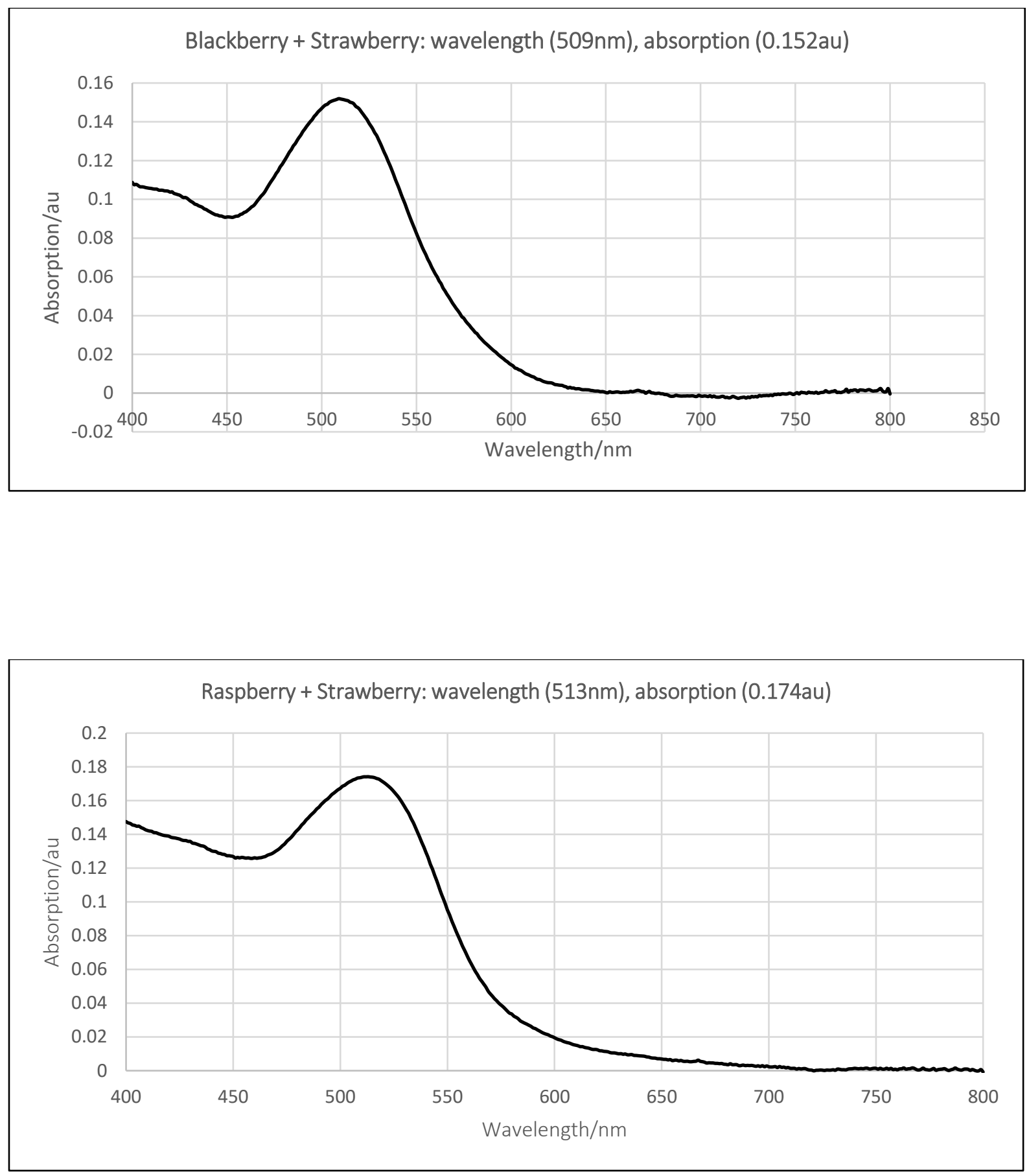

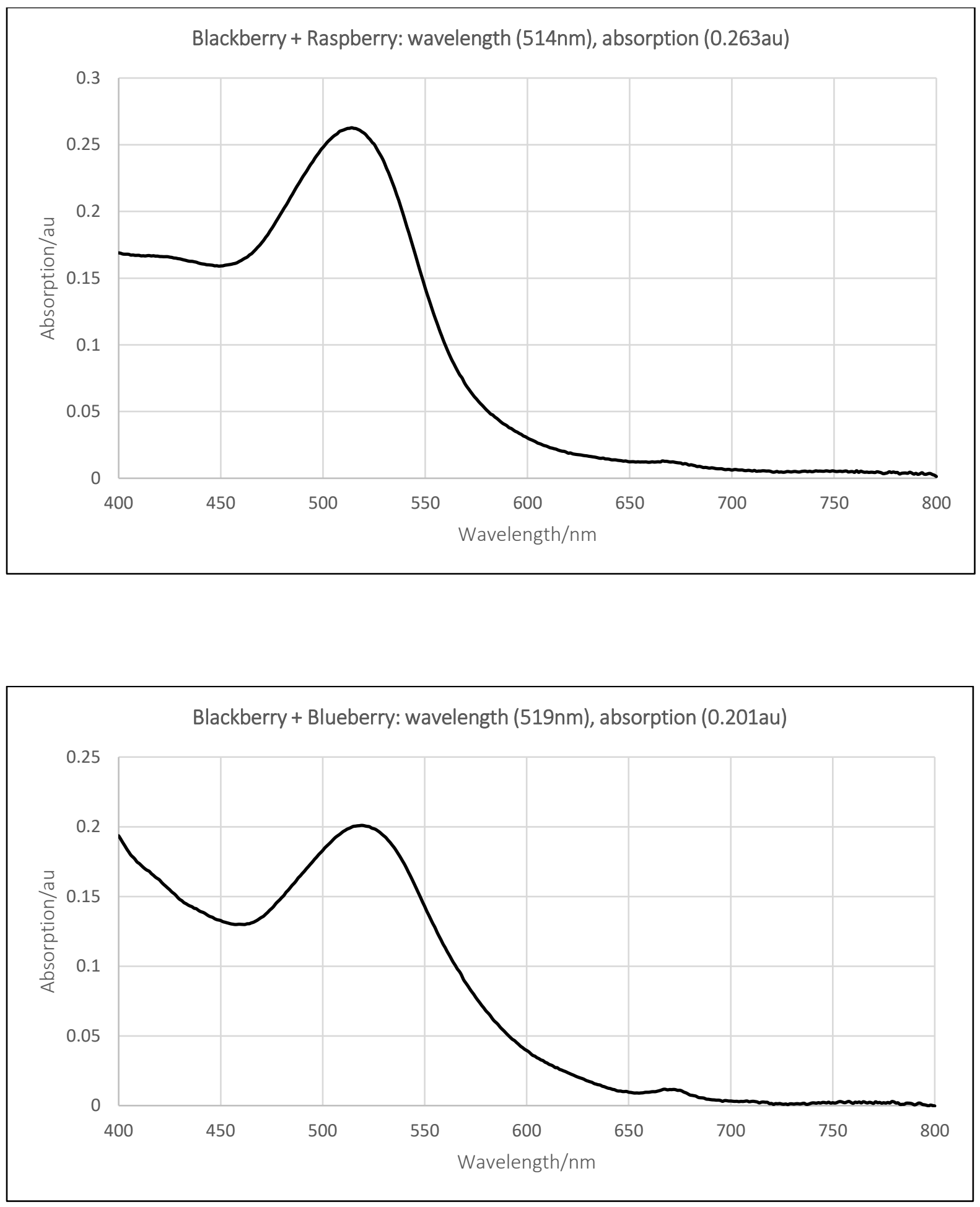

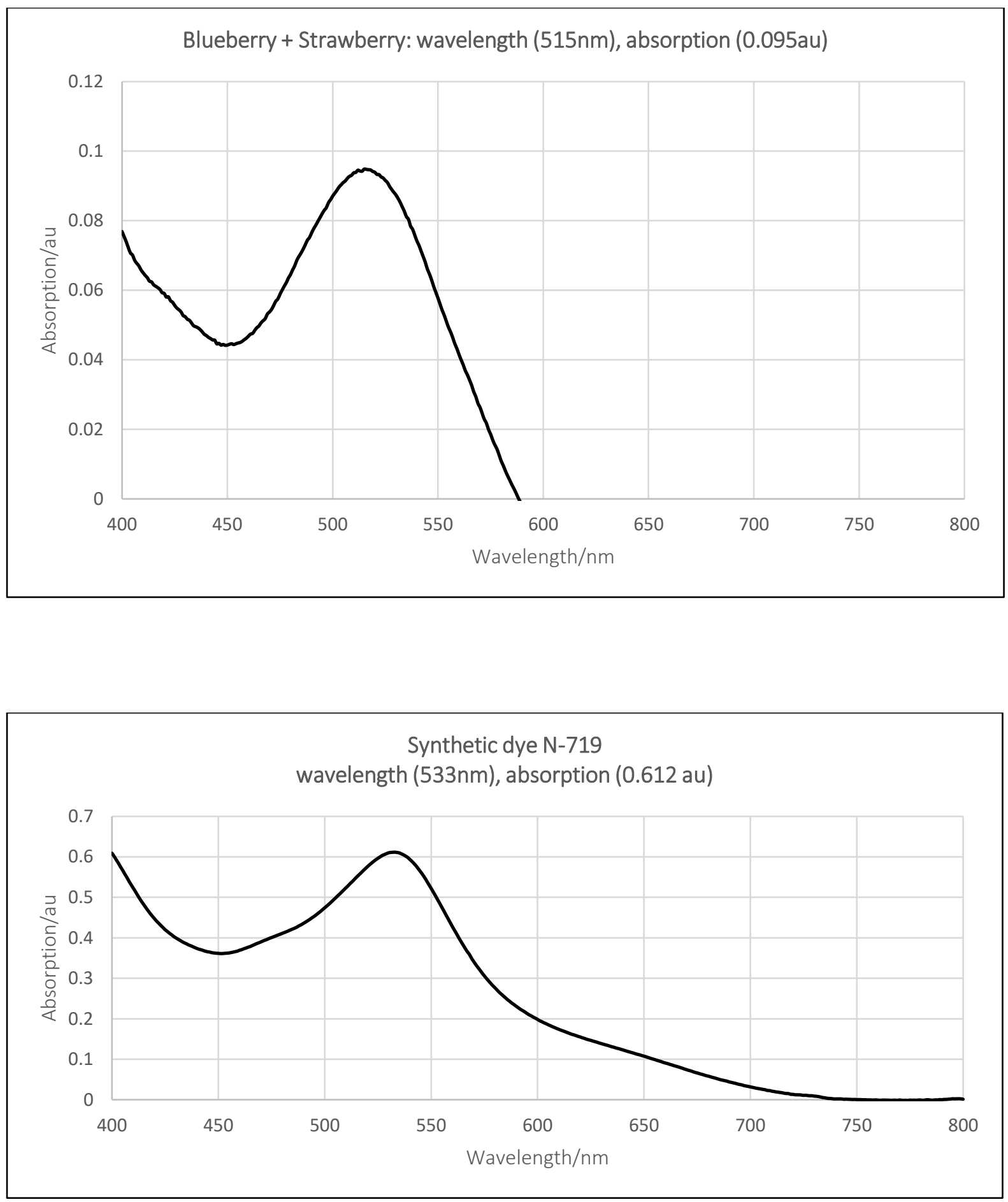